earlier patterns, while efficiency is ten-fold increased. The officer expressed regret that all the men at the front could not have had the latest type before the signing of the armistice.

Colonel William H. Walker, the commanding officer of the Edgewood Arsenal, and a prominent member of the Society, summarized the achievements of the gas offensive program of the Government. "We had," he stated, "on November in of this year all the facilities for producing mustard gas at the rate of rootons a day, to say nothing of our resources for deluging our enemies with chlorine, phosgene, chlorpictin, and toxic vapors previously unknown to them."

Colonel Walker showed that the errors of extended investigations seeking new and improved processes which caused so much delay in quantity output in some other lines of war activities could not be charged against the chemists. From the outset. he declared, well-known and efficient toxic gases were selected for manufacture in effective quantities, while simultaneously a corps of expert research workers sought for improved methods and products. As a result, there was never a day when the production of materials did not exceed the ability to utilize it. In fact, large quantities were shipped overseas in bulk, because other departments were failing in their delivery of containers. Following the discovery of improved processes of manufacture, more factory units were built, but meanwhile production by the old methods continued until the new plants were ready for operation.

In appreciative words, Colonel Walker paid tribute to the patriotic spirit in which the chemists of the country, for the most part enlisted men, had braved the dangers of the poisonous gas plants, far from the glamour of the real battlefields, and in many cases had made the supreme sacrifice.

He also told of the coöperation which he had received from the private chemical companies throughout the country, and as a part return for their helpfulness, offered to supply thei research laboratories with any quantities of his poisonous materials for experimental purposes.

If gas warfare is to hold a permanent place in war programs, the American chemist is prepared.

\section{THE TRAINING OF THE CHEMIST}

Editor of the Journal of Industrial and Engineering Chemistry:

Every one who is engaged in the work of training chemists welcomes Mr. Church's frank article in the December number of THIs Journal, on "A Manufacturer's Experience with Graduate Chemical Engineers," and wishes that such helpful suggestions might be more frequently made. That kind of criticism from employers, definite, clearly stated, and friendly, has a positive educational value to young men in the process of training, and is accepted as wise counsel by those who are responsible for that training and who want to know what the manufacturer desires in the chemist he employs. It would not be at all out of place for the Journal, to add to its long list of helpful features an "Educational Column," inviting frequent contributions not only from employers but from teachers as well, in which the former would state their criticisms and desires regardless of how radical they may be or how subversive of existing methods and courses, and the latter would suggest ways in which the training processes could be altered to make possible the attainment of the end sought.

Better still, the Society at large, which has a vital interest in everything that concerns the state of the chemist and chemistry in America, could well have a small, permanent committee on education, whose function should be not only to discuss and criticize curricula and methods, but also to act as a clearing house for suggestions regarding the training of the chemist both from the point of view of the manufacturer and employer, and of the teacher and university. Such a committee, on which a large industry, a leading university, and a small college might be represented, could collect criticisms and suggestions from both sides, and from time to time publish a digest of all of them in the JOURNAL, with recommendations.

Some such scheme was undertaken a few years ago' by a Committee of the American Institute of Chemical Engineers on Chemical Engineering Education. The enlightening report of that committee brought about some desirable changes in the

\footnotetext{
1 ThIS JOURnal, 2 (1910), 430.
}

curricula of a good many institutions where chemists were in training. The new and unplanned-for conditions brought about by the war call for another like intensive study of the present situation in chemical education. Is not such a study well worth the attention of a committee of the AMERICAN CHEMICAL, SoCIETY?

While Mr. Church is stating his ideas on the subject in such a helpful way, and other employers are doubtless echoing the criticisms, it is worth while for a teacher to call attention to difficulties of which every teacher is aware who is trying to meet the ideals he has in the training of the chemist; for it must be remembered that the manufacturer and the teacher are not very far apart in their ideas of what such training should produce. Every teacher of chemists knows for instance that there is a serious loss of time, both for the employing company and the young chemist, when the latter begins his work. Every teacher knows that for a period varying from three months to a year after the school experience, the employing company is itself a teacher, in some cases supplementing, in some cases correcting, what the young man has learned in his college or university. Every teacher feels responsible for this loss of time and overlapping of effort, while at the same time he knows that in part at least the causes are beyond his control. One of those causes is worth emphatic and repeated statement until it is definitely removed.

Most of the criticisms of the training a chemist receives in the college or technical school or university come to this: the graduate lacks judgment and imagination. That is no news to the men who have trained him. They have struggled to get better results, but granting that the young man has these qualities latent within him when he comes into the institution, the mechanical character of his preparation, and the accepted method of laboratory instruction in chemistry in the early years of the course, as exemplified in most textbooks on the subject, constitute a severe handicap. It is difficult for anyone who has never taught to realize how much the college student uses his memory and how little he uses his reasoning power-how mechanical his work is. If he has had chemistry, or physics, or science work of any kind in his preparatory school, the directions for such work are given him in minutest detail by his laboratory mantual or his instructor. His judgment has not been called into action. Perhaps that is the method that must be used with students of preparatory school age. When that student, so trained, comes to college, the struggle begins between him and his new set of teachers to break this mental habit of expecting. and following detailed directions. For a couple of years, in some cases for the entire four years of the course, the teacher does most of the struggling.

The teacher is not greatly aided in the struggle to develop. judgment and imagination by most of the modern, and in other respects excellent, laboratory mantuals in chemistry. Any good book of that character, either in general chemistry, or analytical chemistry, or organic chemistry, affords abundant illustration of what is here complained of. Directions are given in such detail that the young man does not dare to be independent, is almost afraid to take his finger off the particular line of printing in his manual of directions which he is following lest he do something in a different way-a way that might give just as good a chemical result and a much more valuable mental result. Many a student is lost in the chemical laboratory when he gets a few feet away from his textbook. The question always in his mind is, "What shall I do next?" and if his instructor or textbook is not conveniently near, he feels chemically utterly forsaken. The freshman who wanted to know whether gunpowder would deflagrate on charcoal before a blowpipe, and tried it, is. more promising as an embryo chemist than the other freshman who was given a $250 \mathrm{cc}$. glass balloon with the simple direction. to get the weight of 22.4 liters of carbon dioxide at standard conditions of temperature and pressure, who got the weight of 
the balloon and gas, and then appealed to his instructor with "What shall I do now?" The last-named young man had had a year of preparatory school chemistry and several months in a college laboratory. Experience of many years in teaching and personal inspection of conditions in the chemical laboratories of most of the well-known institutions in this country lead one to believe that dependence and a general helplessness are far too common among students.

In reply to the above criticism of textbooks and methods, it will be urged that that particular plan of instruction is necessary to save the time of the student, to lead him by the shortest route to the result he ought to get. The prefaces of some chemistry books state frankly that the plan of the book is designed to save time, and to reduce to a minimum the amount of instruction required from the instructor. As if time were the most important consideration! As if only books and men can teach! Have mistakes lost all their power of teaching?

If the student has not the time to make mistakes, has he not the right to demand that that privilege be given him?

This is the gist of the whole matter, and the suggestion from an employer that the course of training for chemists be continued for five years, or six years, meets hearty favorable response from every teacher of chemistry. The teacher knows that the present four years (thirty-six months) is inadequate time in which to accomplish what he agrees with the employer is the end to be attained, namely, the development of the judgment and the imagination. Into these thirty-six months are now crowded courses in language, mathematics, physics, electricity, logic, history, economics, and many of the branches of chemical science. The result is likely to be an accumulation of information rather than a deepening of mental processes. The student uses his memory ("crams" is the college students' expressive word), passes examinations, but does not get a great deal of opportunity to use his judgment and his imagination. More time for the course would remove much of this mechanical character of the training.

How can an extension of the time given to training be brought about?

The larger universities can adopt an independent policy in the matter and organize their courses as they judge is best for the cause. Some have already done so, and have made engineering courses, including that of chemical engineering, of graduate character. But such action on the part of one college, regardless of sister institutions, would be disastrous to it. Competition among these institutions is too keen, parents and boys are too impatient to bring to an end the so-called "educational" portion of a boy's training. No one college can require five or six years for an engineering course if other colleges give a course in less time, and if industries take on young men who have had only four years of training.

Here is where the AMERICAN CHEMICAL SOCIETY and similar organizations can do a great work in advancing the cause of chemical education in America. Such societies can take a positive, definite action favoring five or six years as the minimum period for the training of the chemist. They can communicate such action to the presidents of all the institutions in the country, where chemists are being trained. Later, after giving sufficient opportunity for making changes, the Society could classify educational institutions in accordance with the length of time given to chemical training, make public such classification and stamp with its approval the institutions which have extended their courses. The Society would thus be doing for chemical education in America what the Carnegie Foundation for the Advancement of Teaching did, with such far-reaching and altogether beneficial results, for medical education in this country.

Industries themselves have it within their power to become a very effective help in bringing about this desirable extension of time. If the great concerns which employ chemists would refuse to accept any who had not had five or six years of training, the educational institutions would respond by providing the training called for.

Does this read like a call for help? Frankly it is such, just as Mr. Church's criticism of the graduate in chemistry is a call for help. His call is addressed to educational institutions. This call is addressed to the AmERican Chemical Socretry and to industry. Is a committee of the Society to study and report on the situation entirely out of the question? Cannot industrial organizations and universities and colleges get together in some definite way? Cannot these forces unite to bring about what everybody knows is a needed reform?

UNION COLIEGE

SCHENECTADY, N. Y.

January 2, 1919

\section{A LETTER FROM BELGIUM}

To the President of the American Chemical Society:

The Belgian laboratories were formerly accustomed to being supplied, till I9I4, with apparatus and products coming from Germany.

As you can understand, there is here in Belgium a general wish to prevent all trade with that country, and to provide ourselves in America, England, and France.

Would you be so kind as to invite the chemical trade firms of the United States to send us catalogues, information, and addresses, so that we should be able henceforth to send our orders to your country?

With many thanks, yours very truly,

(Signed) A. J. J. VANDERAIDE

LABORATOIRE DE LA VILLE DE GAND

RUE DE LA BrBLIOTHËQU

GHENT, Bei,GIUM, December 11, 1918

Director

\section{RAMSAY MEMORIAL FUND IN AMERICA}

Contributions to the Ramsay Memorial Fund in the United States now amount to $\$ 3000$. It is the desire of the American Committee of the Ramsay Memorial Fund to make the fund an expression of the esteem for Sir William Ramsay in this country. Many have expressed a wish to contribute, but have held back on account of their inability to send in a sum commensurate with their esteem. This has been due to the numerous calls upon all for the past two years. Small sums, from one to five dollars, will be welcomed by the committee, which is anxious to make the expression of appreciation as widespread as possible. Contributions may be sent to Prof. Charles Baskerville, Chairman, College of the City of New York, or Mr. W. J. Matheson, Treasurer, 2 I Burling Slip, New York City.

\section{SOME APPLICATIONS OF PHYSICAL CHEMISTRY IN THE COAL-TAR INDUSTRY-CORRECTION}

In the article printed under the above title [THIs JourNaL, Io (1918), I0I6] the following change should be made:

Page IoI9, table, 5th col., last figure-“"o.1047" should read "o.01047." WILBERT J. HUFF

\section{AN ANAEROBIC CULTURE VOLUMETER-CORRECTION}

In my article under the above title [THIs JourNaL, ro (I9r8), 624 ] the following correction should be made:

Page 625, and col., third line from the end of the article, "stimulates" should read "simulates,"

ZAE NORTHRUP 